\section{Socioeconomic inequalities in the consumption of fruits and vegetables: Colombian National Nutrition Survey, 2010}

\author{
Inequidades socioeconómicas en el consumo \\ de frutas y verduras: Encuesta Nacional de la \\ Situación Nutricional, Colombia, 2010
}

\section{Desigualdades socioeconômicas no consumo de frutas e vegetais: Inquérito Nacional de Situação Nutricional, Colômbia, 2010}

Oscar Fernando Herran 1 Gonzalo Alberto Patiño 1 Edna Magaly Gamboa 1

doi: $10.1590 / 0102-311 \times 00031418$

\begin{abstract}
The objective of this study was to estimate inequalities in the consumption of fruits and vegetables. A multilevel study was performed based on crosssectional data of adults from 18 to 64 years of age $(n=5,217)$ and in geodemographic units $(n=33)$. The consumption of fruits and vegetables was estimated with a food frequency questionnaire administered as part of the 2010 Colombian National Nutrition Survey (ENSIN). Inequality indices for the consumption of whole fruits and fruit juice and for raw and cooked vegetables were estimated using data on wealth, food security, geographical area and monetary poverty. The prevalence of the consumption of cooked vegetables was 64.8\% (95\%CI: 59.2-70.4) among men and the prevalence of the consumption of fruit juice was $86.1 \%$ (95\%CI: 82.4-89.8) among women. The frequency of the consumption of fruit juice was 1.03 times/day (95\%CI: 0.93-1.14) among women. The prevalence and frequency fruits and vegetables consumption per day for the three socioeconomic variables considered in this study are higher according to the higher socioeconomic level $(p<0.05)$, except for the consumption frequency of whole fruits/day $(p=0.24)$. At the individual level, the Gini coefficient for frequency/day ranged from 0.51 to 0.62 . At the ecological level, the Gini index for prevalence ranged from 0.04 to 0.14 ; and for frequency/day ranged from 0.03 to 0.11 . The Colombian population does not meet fruits and vegetables consumption recommendations. Men and women favor the consumption of fruit juice over whole fruits. The inequality in vegetable consumption is clear, with men at a disadvantage. The poor eat fewer fruits and vegetables.
\end{abstract}

Health Status Disparities; Fruit; Vegetables; Nutrition Surveys
Correspondence

O. F. Herran

Escuela de Nutrición y Dietética, Universidad Industrial de Santander.

Carrera 32 No. 29-31. Oficina 304 (CIE), Bucaramanga /

Santader - 68001000, Colombia.

oscar.herran@gmail.com

1 Universidad Industrial de Santander, Bucaramanga, Colombia. 


\section{Introduction}

The prevalence, frequency and quantity of consumption of fruits and vegetables are protective factors against the development of cardiovascular diseases and some types of cancer 1,2,3,4. Fruit and vegetables consumption is determined by structural factors, including production, trade, preservation, price structure, degree of urbanism and income, and equally complex individual factors, such as social representations of consumption, link to the production system, health perceptions, and the education and sex of subjects 5,6,7,8,9. Colombia presents low fruits and vegetables consumption indices. More than $60 \%$ of the population consumes no fruits or vegetables daily. Among consumers, the average consumption frequency is 2.5 times/week for fruits and 4.5 times/week for vegetables. These values are considered low for Latin American countries 8,9,10. Consumption under 400g/day and consumption frequency under five times per day, as recommended by the World Health Organization (WHO), does not protect against the development of mediators of cardiovascular diseases 11,12.

Although fruits and vegetables such as whole grains and vegetables are sources of fiber, they are particularly valued for their vitamin and mineral content and their antioxidant properties 13,14,15. These two food groups are regularly discussed as a single group. However, fruit consumption follows a complementary, albeit different, food culture from that of vegetables 8,9 . Although they share structural factors $4,5,6,8,9$, they do not necessarily share personal factors, which is the level at which fruits and vegetables consumption occurs. Factors such as fruits and vegetables cost, availability, perishability, type of processing or cooking, palatability, and symbolic valuation differentiate their consumption by sex and socioeconomic level 16,17,18,19,20,21,22,23.

Colombia, like all countries in this region of the Americas, has experienced changes in its food patterns given the context of economic growth, with profound social and economic inequalities 24,25,26. The interest in assessing nutritional inequalities and the prevalence and daily frequency of fruits and vegetables consumption results from the concern for achieving equity by promoting individuals' potential to reach their maximum nutritional status, reducing limiting factors, and focusing on aspects that are considered inequitable and avoidable 27,28,29,30. This analysis is a study of "economic inequalities in nutrition" 31 that focuses on adults between 18 and 64 years of age, such age group was chosen because the analysis of inequalities often emphasizes the socioeconomic dimension. Studies on nutritional inequalities often focus on the nutritional status - malnutrition or obesity -, seldom on food consumption and even less often on inequalities in the consumption of a specific food or food group. The results presented here at the individual and ecological levels contribute to bridging this knowledge gap. The analysis of economic inequalities in fruits and vegetables consumption is relevant in the nutrition and medicine fields, in sciences such as economics, epidemiology and econometry, as well as for statisticians and other social scientists, therefore, the results of inequality indexes used by these disciplines may be contradictory, and several of these indexes must be included, calculated and interpreted together.

The objective of this study was to estimate the prevalence and daily frequency of fruits and vegetables consumption among Colombian men and women and the inequalities in fruits and vegetables consumption.

\section{Materials and methods}

\section{Multilevel study}

At the individual level, the study considered subjects between 18 and 64 years of age who were interviewed in the 2010 Colombian National Nutrition Survey (ENSIN-2010). At the ecological level, the study considered the average consumption of fruits and vegetables in the geodemographic units of Colombia 32 . 


\section{Study population}

The participants of ENSIN-2010 were selected to represent $99 \%$ of the population through multistage stratified sampling. All municipalities of the 32 departments and the capital (geodemographic units) were clustered in strata with similar sociodemographic characteristics. Strata were represented by randomly selected municipalities and by maintaining the proportional probability of each stratum size. Ten-household clusters were randomly selected from each stratum. Household members from 50,670 households were invited to participate in the survey. fruits and vegetables consumption was estimated using a food frequency questionnaire (FFQ) administered to 17,897 subjects, 11,320 of whom were from 5 to 17 years of age and 6,577 of whom were from 18 to 64 years of age. The details of the method were previously published 32 .

\section{Sample}

After excluding pregnant women $(\mathrm{n}=137)$ from the study and limiting the analysis to subjects with plausible weight $(>40 \mathrm{~kg}$ and $<200 \mathrm{~kg}$ ) and height $(>100 \mathrm{~cm}$ and $<200 \mathrm{~cm})$ data, fruits and vegetables consumption data from 5,217 subjects between 18 and 64 years of age were analyzed at the individual level. At the ecological level, the sample size was 33 , which corresponds to the total number of geodemographic units of Colombia.

\section{Study variables}

Eight variables were studied differentially according to sex for the two levels of analysis: consumption prevalence of whole fruits and juice, consumption prevalence of raw and cooked vegetables, frequen$\mathrm{cy} /$ day of consumption (times/day) of whole fruits, juice, consumption of raw and cooked vegetables.

At the individual level, the socioeconomic variables related to fruits and vegetables consumption were sex, income, household food security level and the geographical area of residence. These variables were assessed in the ENSIN-2010. At the ecological level, the socioeconomic variable related to consumption was the monetary poverty of each geodemographic unit reported by the Colombian National Administrative Department of Statistics (DANE) in 201133.

\section{Prevalence and frequency of consumption}

ENSIN-2010 assessed the consumption of 30 foods or food groups and three related practices through an FFQ using ten response categories for the previous month ${ }^{32}$. The FFQ was administered by direct interviews performed by dietitian-nutritionists, and the answers were recorded on a personal digital assistant. The Colombian Family Welfare Institute (ICBF) obtained informed consent from all participants prior to enrollment 32 . Four of the food groups were particularly interesting for this analysis: (a) fruit juice, (b) whole fruits, (c) raw vegetables (e.g., tomato, lettuce, cabbage, and carrot), and (d) cooked vegetables (e.g., pumpkin, chard, carrot, spinach, beans, broccoli, and cauliflower). The FFQ provides two answers to each item assessed: (a) whether the respondent consumes the item or not, which allows the probability and the population prevalence related to its consumption to be calculated [probability x 100] and (b) the frequency with which the item was consumed in the last month. The answer regarding frequency is a continuous variable, which was calculated to represent the frequency of consumption/day of the item $34,35,36,37$.

\section{Wealth index}

The level of wealth was assessed in the ENSIN-2010 with a survey designed for international demographic and health analyses 38 . This is a continuous index that assesses family wealth through principal component analysis using various socioeconomic indicators, including household assets, type of land, number of rooms per person, and mode of transportation. This variable was classified into quintiles. 


\section{Level of household food safety}

The level of household food safety was identified in the ENSIN-2010 using a modified version of the questionnaire administered in the Community Childhood Hunger Identification Project 39, which was adapted and validated for the population of Colombia 32,40 .

\section{Geographical area}

The geographical area was classified into three categories: urban areas, small villages and dispersed populations. In Colombia, cities with high population density and capital cities are considered urban areas; these areas have the highest level of human and structural development. Intermediate cities are defined by a population size of less than 500,000 inhabitants or their status as municipal seats which are areas with low population density converge. Villages with low population density are at the end of the development scale 32 .

\section{Monetary poverty}

In Colombia, there are two ways of officially measuring poverty: the multidimensional poverty index and the best-known index that assesses poverty based on household monetary income, also known as monetary poverty 33 . The DANE has calculated and regularly reported this index using the same method since 2011, thereby allowing for the replication of this analysis in future ENSIN for time series comparisons. Monetary poverty data were collected from regional bulletins, one per geodemographic unit, published on the official DANE website. There was no indication that monetary poverty in 2010 differed from the level estimated in 201133 .

\section{Statistical analysis}

The calculations for the prevalence and frequency of consumption per day incorporated a complex sample design and were performed in the Stata software, version 14.1 (https://www.stata.com). The mean values of prevalence and frequency of consumption per day were calculated for each geodemographic unit and outlined in a data table (Table 1). The analysis focused on (a) assessing whether fruits and vegetables consumption (prevalence and frequency/day) and its inequalities differ by sex and (b) identifying inequalities in Colombia regarding the eight variables related to fruits and vegetables consumption using the wealth index, level of household food security, geographical area, and monetary poverty as economic references. At the individual level, the prevalence and frequency of consumption per day were compared based on the levels of covariates using the chi-square test and the linear trend test for nominal and ordinal predictors. For this purpose, crude and adjusted linear and binomial regression models were constructed using the covariates of sex, age, level of wealth, household food security, and geographical area, always incorporating the complex sample design. At the ecological level, the inequality indices were calculated in the Epidat software, version 4.1 (http:// dxsp.sergas.es/default.asp).

\section{Inequality indexes}

In this study, 20 inequality indexes were included and estimated. There is no hierarchy among indexes and their results are not comparable to each other. As previously mentioned, the inequality indexes were calculated considering various disciplinary interests, study objects and objectives, as well as the study construct or field - here, the economic field. Inequality is more likely to occur with no interpretive ambiguities if it is confirmed through multiple indexes. The indexes were calculated based on ranges (ratios of extreme rates, differences in extreme rates, population attributable risk); on disparity (Pearcy-Keppel disparity index and variance between groups); on disproportionality (Gini and Concentration coefficients); on regression models (of effect, slope inequality, the Pamuk, Kunst and Mackenbach relative index of inequality and bounded inequality); and on the concept of enthropy (Kullback-Libler, Hoover, Theil) 6, 30,31,32,41. 
Table 1

Prevalence and frequency/day of fruit and vegetable consumption among adults (18 to 64 years), according to the geodemographic unit and sex. 2010 Colombian National Nutrition Survey (ENSIN).

\begin{tabular}{|c|c|c|c|c|c|c|c|c|c|c|c|c|c|c|c|c|}
\hline \multirow{4}{*}{$\begin{array}{l}\text { Geodemographic } \\
\text { unit }\end{array}$} & \multicolumn{8}{|c|}{ Fruits } & \multicolumn{8}{|c|}{ Vegetables } \\
\hline & \multicolumn{4}{|c|}{ Juice } & \multicolumn{4}{|c|}{ Whole } & \multicolumn{4}{|c|}{ Raw } & \multicolumn{4}{|c|}{ Cooked } \\
\hline & \multicolumn{2}{|c|}{ Male } & \multicolumn{2}{|c|}{ Female } & \multicolumn{2}{|c|}{ Male } & \multicolumn{2}{|c|}{ Female } & \multicolumn{2}{|c|}{ Male } & \multicolumn{2}{|c|}{ Female } & \multicolumn{2}{|c|}{ Male } & \multicolumn{2}{|c|}{ Female } \\
\hline & $\%$ & $\begin{array}{c}\text { Times/ } \\
\text { day }\end{array}$ & $\%$ & $\begin{array}{c}\text { Times/ } \\
\text { day }\end{array}$ & $\%$ & $\begin{array}{c}\text { Times/ } \\
\text { day }\end{array}$ & $\%$ & $\begin{array}{c}\text { Times/ } \\
\text { day }\end{array}$ & $\%$ & $\begin{array}{c}\text { Times/ } \\
\text { day }\end{array}$ & $\%$ & $\begin{array}{c}\text { Times/ } \\
\text { day }\end{array}$ & $\%$ & $\begin{array}{c}\text { Times/ } \\
\text { day }\end{array}$ & $\%$ & $\begin{array}{c}\text { Times/ } \\
\text { day }\end{array}$ \\
\hline Antioquia & 87.6 & 0.8 & 82.7 & 0.9 & 81.6 & 0.6 & 81.0 & 0.5 & 88.4 & 0.5 & 81.3 & 0.4 & 52.7 & 0.2 & 52.1 & 0.3 \\
\hline Atlántico & 86.5 & 0.9 & 94.3 & 0.9 & 74.9 & 0.5 & 67.8 & 0.4 & 77.8 & 0.5 & 88.0 & 0.5 & 66.0 & 0.3 & 78.4 & 0.4 \\
\hline Bogotá, D.C. & 92.6 & 1.2 & 91.4 & 1.1 & 91.9 & 0.6 & 86.2 & 0.7 & 83.8 & 0.5 & 89.1 & 0.5 & 93.2 & 0.5 & 92.5 & 0.5 \\
\hline Bolívar & 90.6 & 1.0 & 99.3 & 1.4 & 87.8 & 0.4 & 92.4 & 0.6 & 78.6 & 0.4 & 88.5 & 0.6 & 66.8 & 0.5 & 78.1 & 0.5 \\
\hline Boyacá & 77.0 & 0.6 & 93.5 & 1.1 & 87.7 & 0.4 & 86.7 & 0.6 & 84.8 & 0.4 & 88.0 & 0.5 & 77.2 & 0.3 & 85.6 & 0.4 \\
\hline Caldas & 88.3 & 0.7 & 86.9 & 0.9 & 86.0 & 0.6 & 76.3 & 0.4 & 71.1 & 0.4 & 79.7 & 0.4 & 60.1 & 0.2 & 65.2 & 0.2 \\
\hline Caquetá & 89.0 & 1.0 & 79.1 & 0.9 & 72.1 & 0.3 & 77.7 & 0.4 & 77.9 & 0.3 & 81.0 & 0.4 & 41.7 & 0.1 & 55.5 & 0.2 \\
\hline Cauca & 83.3 & 0.9 & 78.6 & 0.9 & 81.1 & 0.4 & 71.4 & 0.3 & 79.5 & 0.4 & 72.7 & 0.4 & 61.8 & 0.3 & 63.9 & 0.4 \\
\hline Cesar & 92.9 & 1.1 & 86.0 & 1.1 & 81.0 & 0.6 & 73.6 & 0.6 & 85.6 & 0.5 & 83.1 & 0.5 & 70.1 & 0.2 & 68.0 & 0.3 \\
\hline Córdoba & 86.9 & 1.1 & 93.0 & 1.2 & 89.5 & 0.8 & 92.8 & 0.8 & 80.3 & 0.4 & 88.8 & 0.5 & 83.4 & 0.3 & 85.2 & 0.4 \\
\hline Cundinamarca & 93.0 & 1.2 & 80.3 & 1.0 & 84.4 & 0.4 & 83.4 & 0.6 & 80.4 & 0.3 & 87.6 & 0.5 & 77.0 & 0.4 & 90.9 & 0.4 \\
\hline Chocó & 98.0 & 0.9 & 94.4 & 1.1 & 79.6 & 0.4 & 80.2 & 0.4 & 70.2 & 0.3 & 76.3 & 0.4 & 67.8 & 0.4 & 68.9 & 0.3 \\
\hline Huila & 95.4 & 1.2 & 91.5 & 1.3 & 92.4 & 0.4 & 89.4 & 0.5 & 86.7 & 0.5 & 91.9 & 0.5 & 78.2 & 0.3 & 83.8 & 0.5 \\
\hline La Guajira & 76.8 & 0.8 & 87.1 & 1.2 & 89.3 & 0.5 & 89.4 & 0.6 & 52.8 & 0.3 & 84.3 & 0.4 & 58.2 & 0.2 & 66.9 & 0.2 \\
\hline Magdalena & 91.1 & 1.0 & 86.3 & 1.0 & 88.8 & 0.8 & 74.7 & 0.6 & 81.7 & 0.6 & 76.6 & 0.5 & 55.1 & 0.3 & 62.2 & 0.4 \\
\hline Meta & 92.5 & 1.3 & 88.3 & 1.6 & 76.5 & 0.3 & 81.4 & 0.4 & 75.7 & 0.4 & 79.4 & 0.5 & 79.4 & 0.4 & 88.6 & 0.4 \\
\hline Nariño & 89.4 & 0.9 & 89.6 & 1.1 & 81.8 & 0.4 & 83.9 & 0.6 & 76.0 & 0.3 & 79.4 & 0.4 & 62.7 & 0.3 & 77.1 & 0.3 \\
\hline Norte de Santander & 76.4 & 0.7 & 91.8 & 1.0 & 68.5 & 0.3 & 78.9 & 0.4 & 71.8 & 0.4 & 84.2 & 0.5 & 49.7 & 0.3 & 70.1 & 0.3 \\
\hline Quindío & 80.7 & 1.1 & 81.9 & 1.0 & 67.4 & 0.4 & 70.5 & 0.4 & 84.9 & 0.4 & 76.8 & 0.5 & 51.4 & 0.2 & 52.8 & 0.3 \\
\hline Risaralda & 79.9 & 0.9 & 79.3 & 0.9 & 72.7 & 0.6 & 76.2 & 0.5 & 68.0 & 0.4 & 83.9 & 0.5 & 56.4 & 0.3 & 65.5 & 0.3 \\
\hline Santander & 89.7 & 0.8 & 92.4 & 1.0 & 71.1 & 0.4 & 86.6 & 0.5 & 72.3 & 0.4 & 83.6 & 0.5 & 68.0 & 0.3 & 79.8 & 0.3 \\
\hline Sucre & 89.7 & 0.9 & 91.9 & 1.4 & 88.3 & 0.7 & 82.6 & 0.6 & 77.8 & 0.3 & 82.0 & 0.5 & 75.0 & 0.4 & 83.8 & 0.5 \\
\hline Tolima & 91.7 & 1.1 & 94.4 & 1.1 & 87.6 & 0.4 & 81.4 & 0.7 & 69.4 & 0.3 & 79.1 & 0.4 & 66.7 & 0.4 & 71.6 & 0.3 \\
\hline Valle del Cauca & 91.1 & 1.3 & 89.4 & 1.4 & 79.3 & 0.5 & 75.7 & 0.5 & 86.0 & 0.6 & 88.5 & 0.6 & 66.4 & 0.2 & 70.3 & 0.3 \\
\hline Arauca & 93.5 & 1.3 & 100.0 & 1.2 & 88.6 & 0.5 & 86.6 & 0.6 & 96.4 & 0.5 & 94.3 & 0.5 & 99.3 & 0.6 & 99.3 & 0.5 \\
\hline Casanare & 87.4 & 1.0 & 89.5 & 1.3 & 80.9 & 0.4 & 67.1 & 0.4 & 65.8 & 0.4 & 84.7 & 0.6 & 75.4 & 0.3 & 87.1 & 0.4 \\
\hline Putumayo & 84.0 & 0.7 & 83.5 & 0.7 & 71.0 & 0.3 & 78.5 & 0.3 & 74.0 & 0.3 & 90.0 & 0.4 & 58.6 & 0.2 & 62.4 & 0.3 \\
\hline San Andrés y & 77.5 & 0.6 & 83.7 & 0.8 & 87.9 & 0.5 & 85.9 & 0.5 & 86.5 & 0.5 & 84.8 & 0.5 & 51.2 & 0.3 & 71.6 & 0.4 \\
\hline \multicolumn{17}{|l|}{ Providencia } \\
\hline Amazonas & 76.6 & 0.7 & 73.4 & 0.7 & 66.2 & 0.4 & 70.7 & 0.4 & 62.8 & 0.3 & 49.2 & 0.2 & 23.1 & 0.1 & 21.4 & 0.1 \\
\hline Guainía & 61.1 & 0.5 & 76.4 & 0.6 & 58.1 & 0.3 & 77.8 & 0.2 & 64.7 & 0.3 & 61.5 & 0.2 & 40.1 & 0.1 & 36.5 & 0.2 \\
\hline Guaviare & 95.3 & 1.1 & 99.4 & 1.5 & 92.1 & 0.6 & 96.0 & 0.5 & 88.2 & 0.4 & 91.2 & 0.4 & 85.6 & 0.3 & 83.2 & 0.4 \\
\hline Vaupés & 66.2 & 0.5 & 49.3 & 0.3 & 63.4 & 0.2 & 66.9 & 0.2 & 52.3 & 0.3 & 55.6 & 0.2 & 49.7 & 0.1 & 36.1 & 0.2 \\
\hline Vichada & 76.5 & 1.2 & 62.1 & 0.3 & 98.2 & 0.3 & 84.4 & 0.3 & 76.2 & 0.2 & 72.8 & 0.3 & 71.3 & 0.2 & 52.1 & 0.1 \\
\hline
\end{tabular}




\section{Results}

\section{Individual level}

The mean age of men in this study was 37.7 years (95\%CI: 37.0-38.4), and the mean age of women was 38.5 years (95\%CI: 37.9-39.1).

\section{Prevalence of consumption of fruits and vegetables}

The prevalence of consumption of whole fruits was $83.3 \%$ (95\%CI: 81.2-85.2) among men and 81.7\% (95\%CI: 79.7-83.4) among women. The prevalence of consumption of fruit juice was $88.9 \%$ (95\%CI: 87.1-90.6) among men and 88.6\% (95\%CI: 86.8-90.2) among women. The prevalence of consumption of raw vegetables was $80.9 \%$ (95\%CI: 78.8-82.9) among men and 84.9\% (95\%CI: 83.0-86.5) among women. The prevalence of consumption of cooked vegetables was 69.8\% (95\%CI: 67.3-72.3) among men and 75.1\% (95\%CI: 72.9-77.1) among women.

\section{Frequency of consumption of fruits and vegetables (times/day)}

The frequency of consumption of whole fruits was 0.51 times/day (95\%CI: 0.48-0.55) among men and 0.51 times/day (95\%CI: 0.48-0.54) among women. The frequency of consumption of fruit juice was 0.98 times/day (95\%CI: 0.92-1.03) among men and 1.02 times/day (95\%CI: 0.98-1.07) among women. The frequency of consumption of raw vegetables was 0.43 times/day (95\%CI: 0.41-0.46) among men and 0.46 times/day (95\%CI: 0.44-0.48) among women. The frequency of consumption of cooked vegetables was 0.31 times/day (95\%CI: 0.28-0.33) among men and 0.34 times/day (95\%CI: 0.32-0.36) among women.

\section{Inequality}

The prevalence and frequency of consumption of fruits and vegetables per day for the three socioeconomic variables considered in this study are higher according to the higher socioeconomic levels $(\mathrm{p}<0.05)$, except for the frequency of consumption of whole fruits/day $(\mathrm{p}=0.247)$ (Tables 2 and 3 ).

\section{Ecological level}

The lowest poverty level was found in Bogotá, the capital of Colombia (13.1\%), and the highest was found in Chocó, located on the Pacific coast (64\%). The average percentage of monetary poverty of Columbia at the time of the ENSIN-2010 was 41.5\% (95\%CI: 35.7-47.4).

\section{Prevalence of consumption of fruits and vegetables}

The mean prevalence of consumption of whole fruits was $80.3 \%$ (95\%CI: 77.4-84.3). The mean prevalence of consumption of fruit juice was $85.7 \%$ (95\%CI: 82.7-88.7. The mean prevalence of consumption of raw vegetables was $76.6 \%$ (95\%CI: 73.1-80.1). The mean prevalence of consumption of cooked vegetables was $64.8 \%$ (95\%CI: 59.2-70.4).

\section{Frequency of consumption of fruits and vegetables (times/day)}

The mean frequency of consumption of whole fruits was 0.46 times/day (95\%CI: 0.41-0.52). The mean frequency of consumption of fruit juice was 0.94 times/day (95\%CI: 0.86-1.02). The mean frequency of consumption of raw vegetables was 0.39 times/day (95\%CI: 0.36-0.43). The mean frequency of consumption of cooked vegetables was 0.29 times/day (95\%CI: 0.25-0.33). Table 1 presents the rates of prevalence and frequency of consumption/day by geodemographic unit. 
Table 2

Prevalence of consumption of fruits and vegetables in adults (18 to 64 years) by socioeconomic indicators. 2010 Colombian National Nutrition Survey (ENSIN).

\begin{tabular}{|c|c|c|c|c|}
\hline \multirow[t]{2}{*}{ Variable [n] * } & \multicolumn{2}{|c|}{ Fruits $(\%) * *$} & \multicolumn{2}{|c|}{ Vegetables (\%) ** } \\
\hline & Juice & Whole & Raw & Cooked \\
\hline \multicolumn{5}{|l|}{ Sex } \\
\hline Male $[2,309]$ & 88.9 & 83.3 & 80.9 & 69.8 \\
\hline Female $[2,908]$ & 88.6 & 81.7 & 84.9 & 75.1 \\
\hline p-value $* \star \star$ & 0.771 & 0.243 & 0.005 & 0.001 \\
\hline p-value \# & 0.460 & 0.319 & 0.014 & 0.004 \\
\hline \multicolumn{5}{|l|}{ Wealth index \#\# } \\
\hline Q1 $[1,382]$ the poorest & 75.9 & 77.0 & 73.8 & 61.6 \\
\hline Q2 [1,207] & 86.6 & 80.0 & 80.7 & 64.4 \\
\hline Q3 $[1,064]$ & 89.7 & 80.0 & 84.7 & 70.9 \\
\hline Q4 [857] & 92.8 & 86.7 & 84.9 & 78.4 \\
\hline Q5 [707] the richest & 95.6 & 88.1 & 89.0 & 84.5 \\
\hline $\mathrm{p}$-value $* \star \star$ & $<0.0001$ & $<0.0001$ & $<0.0001$ & $<0.0001$ \\
\hline p-value \# & $<0.0001$ & $<0.0001$ & 0.020 & $<0.0001$ \\
\hline \multicolumn{5}{|l|}{ Household food insecurity } \\
\hline None $[2,011]$ & 93.5 & 88.7 & 86.7 & 78.3 \\
\hline Mild $[1,951]$ & 88.8 & 80.1 & 84.2 & 71.8 \\
\hline Moderate [758] & 84.3 & 74.6 & 77.1 & 68.4 \\
\hline Severe [495] & 72.3 & 73.6 & 69.4 & 55.3 \\
\hline p-value $* \star \star$ & $<0.0001$ & $<0.0001$ & $<0.0001$ & $<0.0001$ \\
\hline p-value \# & $<0.0001$ & $<0.0001$ & $<0.0001$ & $<0.0001$ \\
\hline \multicolumn{5}{|l|}{ Geographic area } \\
\hline City urban area $[3,712]$ & 91.2 & 83.3 & 85.2 & 75.8 \\
\hline Small village [893] & 85.1 & 80.5 & 79.9 & 61.4 \\
\hline Dispersed population [612] & 76.6 & 78.4 & 73.0 & 62.7 \\
\hline p-value $* \star \star$ & $<0.0001$ & 0.051 & $<0.0001$ & $<0.0001$ \\
\hline p-value \# & 0.004 & 0.157 & 0.014 & 0.442 \\
\hline
\end{tabular}

* May be less than 5,217 for missing values;

** Unadjusted prevalence for the categories of socioeconomic variables;

*** p-value for the difference by sex or linear trend test, estimated in a binomial regression model, where the prevalence of consumption (yes/no) is the dependent variable and the predictor economic variable. For the geographical area, the p-value is for the Wald test;

\# p-value for the difference by sex or test for linear trend, estimated in a binomial regression model, where the prevalence of consumption (yes/no) is the dependent variable and the predictors, age (continuous), sex, wealth index, household food insecurity and geographical area. For the geographical area, the p-value is for the Wald test;

\#\# The wealth index is a composite measure of a household's cumulative living standard. The wealth index is calculated using easy-to-collect data on a household's ownership of selected assets, such as televisions and bicycles; materials used for housing construction; and types of water access and sanitation facilities.

\section{Inequality}

- Monetary poverty and consumption: The linear relationship between monetary poverty and the rates of prevalence and frequency/day was weak, with no difference by sex or type of consumption. For all $\beta$ coefficients, $\mathrm{p}>0.05$.

- Range-based inequality: For both men and women, the highest ratios of extreme rates were the prevalence of consumption of fruit juice and the frequency of consumption of whole fruits/day. In the poorest geodemographic unit, Chocó, the prevalence of consumption of fruit juice among men 
Table 3

Frequency/day consumption of fruits and vegetables in adults (18 to 64 years) by socioeconomic indicators. 2010 Colombian National Nutrition Survey (ENSIN).

\begin{tabular}{|c|c|c|c|c|}
\hline \multirow[t]{2}{*}{ Variable $[n]$ * } & \multicolumn{2}{|c|}{ Fruits $(\%) * \star$} & \multicolumn{2}{|c|}{ Vegetables (\%) ** } \\
\hline & Juice & Whole & Raw & Cooked \\
\hline \multicolumn{5}{|l|}{ Sex } \\
\hline Male $[2,309]$ & 0.98 & 0.51 & 0.43 & 0.31 \\
\hline Female $[2,908]$ & 1.02 & 0.51 & 0.46 & 0.34 \\
\hline $\mathrm{p}$-value *** & 0.184 & 0.866 & 0.079 & 0.021 \\
\hline p-value \# & 0.256 & 0.885 & 0.143 & 0.024 \\
\hline \multicolumn{5}{|l|}{ Wealth index \#\# } \\
\hline Q1 $[1,382]$ the poorest & 0.65 & 0.49 & 0.32 & 0.29 \\
\hline Q2 [1,207] & 0.91 & 0.45 & 0.40 & 0.28 \\
\hline Q3 $[1,064]$ & 0.99 & 0.49 & 0.46 & 0.30 \\
\hline Q4 [857] & 1.16 & 0.50 & 0.47 & 0.35 \\
\hline Q5 [707] the richest & 1.20 & 0.61 & 0.54 & 0.40 \\
\hline $\mathrm{p}$-value $* * \star$ & $<0.0001$ & 0.001 & $<0.0001$ & $<0.0001$ \\
\hline p-value \# & $<0.0001$ & 0.080 & 0.003 & 0.001 \\
\hline \multicolumn{5}{|l|}{ Household food insecurity } \\
\hline None $[2,011]$ & 1.16 & 0.60 & 0.51 & 0.37 \\
\hline Mild $[1,951]$ & 0.97 & 0.46 & 0.43 & 0.31 \\
\hline Moderate [758] & 0.82 & 0.44 & 0.34 & 0.31 \\
\hline Severe [495] & 0.63 & 0.41 & 0.37 & 0.22 \\
\hline $\mathrm{p}$-value *** & $<0.0001$ & $<0.0001$ & $<0.0001$ & $<0.0001$ \\
\hline p-value \# & $<0.0001$ & $<0.0001$ & $<0.0001$ & $<0.0001$ \\
\hline \multicolumn{5}{|l|}{ Geographic area } \\
\hline City urban area $[3,712]$ & 1.07 & 0.52 & 0.48 & 0.34 \\
\hline Small village [893] & 0.87 & 0.46 & 0.38 & 0.27 \\
\hline Dispersed population [612] & 0.70 & 0.49 & 0.31 & 0.29 \\
\hline $\mathrm{p}$-value *** & $<0.0001$ & 0.176 & $<0.0001$ & 0.005 \\
\hline p-value \# & 0.117 & 0.906 & 0.002 & 0.813 \\
\hline \multicolumn{5}{|l|}{ Measure of inequality } \\
\hline Gini coefficient & 0.51 & 0.61 & 0.53 & 0.62 \\
\hline
\end{tabular}

* May be less than 5,217 for missing values;

** Unadjusted mean frequency/day for the categories of socioeconomic variables;

*** $\mathrm{p}$-value for the difference by sex or linear trend test, estimated in a linear regression model, where the frequency/ day is the dependent variable and the predictor economic variable. For the geographical area, the p-value is for the Wald test:

\# p-value for the difference by sex or test for linear trend, estimated in a linear regression model, where the frequency/ day is the dependent variable and the predictors, age (continuous), sex, wealth index, household food insecurity and geographical area. For the geographical area, the p-value is for the Wald test;

\#\# The wealth index is a composite measure of a household's cumulative living standard. The wealth index is calculated using easy-to-collect data on a household's ownership of selected assets, such as such as televisions and bicycles; materials used for housing construction; and types of water access and sanitation facilities.

was $6 \%$ higher than in the least poor geodemographic unit, Bogotá, and the consumption frequency of fruit juice/day among men in Chocó was 27\% lower than in Bogotá. In contrast, the consumption prevalence of whole fruits was 13\% lower in Chocó than in Bogotá. If the poverty of the geodemographic units was reduced to the level of Bogotá (13.1\%, the lowest level of poverty), fruit juice consumption prevalence would be expected to increase $4.11 \%$ among men and $3 \%$ among women, and 


\section{Table 4}

Indices of inequality in consumption of fruits and vegetables of men (18 to 64 years), based on monetary poverty. 2010 Colombian National Nutrition Survey (ENSIN).

\begin{tabular}{|c|c|c|c|c|}
\hline \multirow[t]{2}{*}{ Ordered by the socioeconomic variable * } & \multicolumn{2}{|c|}{ Fruits } & \multicolumn{2}{|c|}{ Vegetables } \\
\hline & Juice & Whole & Raw & Cooked \\
\hline \multicolumn{5}{|l|}{ Based on range $(n=24) * *$} \\
\hline \multirow[t]{2}{*}{ Ratio extreme rates } & $0.87 * \star \star$ & 1.06 & 0.84 & 0.73 \\
\hline & $0.61 \#$ & 0.73 & 0.63 & 0.89 \\
\hline \multirow[t]{2}{*}{ Difference in extreme rates } & -12.27 & 5.40 & -13.61 & -25.46 \\
\hline & -0.24 & -0.33 & -19.00 & -0.05 \\
\hline \multirow[t]{2}{*}{ Population attributable prevalence } & -8.71 & -3.66 & -3.13 & -23.67 \\
\hline & -0.09 & -0.20 & -0.07 & -0.15 \\
\hline \multirow[t]{2}{*}{ Population attributable prevalence (\%) } & -10.47 & -4.11 & -3.94 & -34.02 \\
\hline & -17.58 & -19.14 & -14.77 & -46.68 \\
\hline \multicolumn{5}{|l|}{ Based on disparity or dispersion $(n=33)$} \\
\hline \multirow[t]{2}{*}{ Pearcy-Keppel } & 0.10 & 0.07 & 0.10 & 0.18 \\
\hline & 0.26 & 0.19 & 0.21 & 0.29 \\
\hline \multirow[t]{2}{*}{ Ajusted Pearcy-Keppel } & 5.83 & 3.59 & 5.46 & 11.62 \\
\hline & 0.11 & 0.18 & 0.08 & 0.09 \\
\hline \multirow[t]{2}{*}{ Variance between groups (VEG) } & 48.72 & 22.99 & 49.05 & 200.15 \\
\hline & 0.02 & 0.04 & 0.01 & 0.01 \\
\hline \multirow[t]{2}{*}{ Ajusted variance between groups $\left(\mathrm{VEG}_{\mathrm{A}}\right)$} & 0.59 & 0.26 & 0.61 & 2.88 \\
\hline & 0.03 & 0.04 & 0.02 & 0.04 \\
\hline \multicolumn{5}{|c|}{ Based on disproportionality and concentration $(n=24)$} \\
\hline \multirow[t]{2}{*}{ Gini coefficient } & 0.05 & 0.03 & 0.04 & 0.11 \\
\hline & 0.13 & 0.11 & 0.12 & 0.19 \\
\hline \multirow[t]{2}{*}{ Concentration index } & 0.01 & 0.01 & 0.02 & 0.05 \\
\hline & 0.02 & 0.04 & 0.04 & 0.06 \\
\hline \multicolumn{5}{|l|}{ Based on regression models $(n=24)$} \\
\hline \multirow[t]{2}{*}{ Effect index } & -0.05 & -0.11 & -0.15 & -0.43 \\
\hline & -0.00 & -0.01 & -0.00 & -0.00 \\
\hline \multirow[t]{2}{*}{ Inequality slope } & 3.56 & 5.22 & 7.51 & 22.18 \\
\hline & 0.07 & 0.22 & 0.11 & 0.12 \\
\hline \multirow[t]{2}{*}{ Pamuk inequality or relative } & 0.04 & 0.06 & 0.09 & 0.32 \\
\hline & 0.13 & 0.22 & 0.24 & 0.38 \\
\hline \multirow[t]{2}{*}{ Kunst and Mackenbach inequality } & 1.04 & 1.06 & 1.09 & 1.28 \\
\hline & 1.12 & 1.20 & 1.22 & 1.32 \\
\hline \multirow[t]{2}{*}{ Bounded inequality } & 0.96 & 0.95 & 0.92 & 0.74 \\
\hline & 0.89 & 0.82 & 0.80 & 0.70 \\
\hline \multicolumn{5}{|l|}{ Based on the concept of entropy $(n=33)$} \\
\hline \multirow[t]{2}{*}{ Kullback-Liebler (Z score) } & 0.01 & 0.00 & 0.00 & 0.02 \\
\hline & 0.03 & 0.02 & 0.02 & 0.06 \\
\hline \multirow[t]{2}{*}{ Hoover or dissimilarities (Z score) } & 0.03 & 0.02 & 0.03 & 0.08 \\
\hline & 0.10 & 0.09 & 0.09 & 0.14 \\
\hline Theil (Z score) & 0.00 & 0.00 & 0.00 & 0.02 \\
\hline & 0.03 & 0.02 & 0.02 & 0.06 \\
\hline
\end{tabular}

* For all calculations the sense of economic variable was negative, in the health variable is positive;

** $\mathrm{n}$ is 24 that the monetary poverty data is necessary;

$\star * *$ For all indexes the first line is based on the mean prevalence of use (\%);

\# For all indexes the first line is based on the mean frequency/day of consumption (times/day). 
the frequency of consumption/day (times/day) would increase 19.1\% among men and 2.5\% among women, on average. The highest inequality was observed in the prevalence and frequency of consumption of cooked vegetables/day (Tables 4 and 5).

- Disparity-based inequality: For both men and women, the different indices showed that the highest inequality was found in the prevalence of the consumption of cooked vegetables.

- Disproportionality-based inequality: Inequality based on monetary poverty reached the highest Gini coefficient in the frequency of consumption of cooked vegetables/day, 0.19 times/day among men and 0.13 times/day among women.

- Inequality based on effect indices and regression models: For men, weighed $\beta$ or inequality coefficient (ridit score) showed that the lower poverty (higher wealth) is, the higher the prevalence of consumption will be. The effect of monetary poverty on the frequency of consumption/day is close to zero. Similarly, for women, the lower poverty is, the higher the prevalence of consumption of whole fruits and raw and cooked vegetables will be. Except for the prevalence and frequency of consumption of fruit juice/day, with an inverse relationship with poverty "ridit" from -2.32 to -0.08 , respectively.

- Inequality based on the concept of entropy: For men, the standardized coefficients (Z) of the three indices calculated were approximately zero, which is desirable. The highest potential for redistribution is the frequency of consumption of cooked vegetables/day (14\%) based on $\mathrm{Z}=0.14$ (Tables 4 and 5).

\section{Discussion}

Low fruits and vegetables consumption rates in the Colombian adult population have previously been reported 8,9,32,42. ENSIN-2005 assessed a 72.9\% prevalence of consumption of fruits and a $62.1 \%$ prevalence of consumption of vegetables, with $88 \mathrm{~g} /$ day and $46 \mathrm{~g} /$ day medians, respectively 42 . In 2009, a population intervention in children to increase fruits and vegetables consumption found a frequency of consumption of fruits and vegetables/day of 1.4 and 0.4 times/day, respectively 8,9. Based on studies that have used the same FFQ method, low consumption of fruits and vegetables has been reported in countries of the Americas. For example, in Uruguay, adolescents have a median fruits and vegetables consumption of 1 time/day, and an $89 \%$ prevalence of consumption lower than five times a day 17 . In New York (USA), the prevalence of consumption of fruits and vegetables was $12.5 \%$ in 2012, two percentage points lower than the rate in 2002 (14.3\%); thus, leading to considerations about population intervention strategies 5. In Mexico, according to the 2006 National Health and Nutrition Survey, the combined average fruits and vegetables consumption was $122.6 \mathrm{~g}$ for adults, which is equivalent to one or fewer portions of fruits and vegetables/day 43. In 2012, fruits and vegetables consumption among children remained low 44. In Peru, according to a demographic and family health survey conducted in 2013, the consumption of fruits among men was 0.5 times/day and 0.7 times/day among women, on average, with vegetable consumption of 0.4 times/day for men and 0.5 times/day for women 45. In industrialized countries such as Canada and Germany 21,46, average fruits and vegetables consumption is five or more times/day, which increases with age. At least $50 \%$ of the population consumes half or more of the recommended level of vegetables ( $200 \mathrm{~g} / \mathrm{day})$. In Brazil, the prevalence of adequate consumption of fruits and vegetables is low in all regions and among all age groups; the highest prevalence is found among women and increases with age, higher education level and higher socioeconomic status 47 .

Similar to the findings of this study, gender differences in fruits and vegetables consumption have been shown in several studies, with women at an advantage 20,46,48. However, a study conducted among Chilean adults failed to show gender differences in fruits and vegetables consumption 20 . In Germany, women consume more raw vegetables and men consume more cooked vegetables 46 . Studies have shown that both sexes prefer fruits to vegetables. The findings reported herein demonstrate that sex determined the type of consumption of vegetables but not of fruits. Therefore, analyzing fruits and vegetables as a single combined type of consumption has little justification in estimation, analysis, or the implementation of strategies to increase fruits and vegetables consumption. From a culinary standpoint, preparing fruits is not the same as preparing vegetables with regard to ensuring their palatability. Fruits and vegetables also differ when considering their price, the challenge of 


\section{Table 5}

Indices of inequality in consumption of fruits and vegetables of women (18 to 64 years), based on monetary poverty. 2010 Colombian National Nutrition Survey (ENSIN).

\begin{tabular}{|c|c|c|c|c|}
\hline \multirow[t]{2}{*}{ Ordered by the socioeconomic variable * } & \multicolumn{2}{|c|}{ Fruits } & \multicolumn{2}{|c|}{ Vegetables } \\
\hline & Juice & Whole & Raw & Cooked \\
\hline \multicolumn{5}{|l|}{ Based on range $(n=24) * *$} \\
\hline \multirow[t]{2}{*}{ Ratio extreme rates } & $0.93 * * *$ & 1.03 & 0.86 & 0.74 \\
\hline & $0.60 \#$ & 1.01 & 0.77 & 0.73 \\
\hline \multirow[t]{2}{*}{ Difference in extreme rates } & -6.03 & 3.00 & -12.74 & -23.65 \\
\hline & -0.27 & 0.01 & -0.12 & -0.13 \\
\hline \multirow[t]{2}{*}{ Population attributable prevalence } & -4.62 & -2.66 & -4.25 & -17.46 \\
\hline & 0.13 & -0.03 & -0.02 & -0.11 \\
\hline \multirow[t]{2}{*}{ Population attributable prevalence (\%) } & -5.66 & -3.00 & -5.01 & -23.26 \\
\hline & -24.01 & -2.45 & -4.64 & -29.32 \\
\hline \multicolumn{5}{|l|}{ Based on disparity or dispersion $(n=33)$} \\
\hline \multirow[t]{2}{*}{ Pearcy-Keppel } & 0.08 & 0.08 & 0.08 & 0.18 \\
\hline & 0.22 & 0.20 & 0.15 & 0.24 \\
\hline \multirow[t]{2}{*}{ Ajusted Pearcy-Keppel } & 5.14 & 4.46 & 4.01 & 11.91 \\
\hline & 0.10 & 0.15 & 0.05 & 0.08 \\
\hline \multirow[t]{2}{*}{ Variance between groups (VEG) } & 40.95 & 29.65 & 23.51 & 194.50 \\
\hline & 0.01 & 0.03 & 0.00 & 0.01 \\
\hline \multirow[t]{2}{*}{ Ajusted variance between groups ( $\left.V_{E G}\right)$} & 0.50 & 0.33 & 0.28 & 2.59 \\
\hline & 0.02 & 0.03 & 0.01 & 0.02 \\
\hline \multicolumn{5}{|c|}{ Based on disproportionality and concentration $(n=24)$} \\
\hline \multirow[t]{2}{*}{ Gini coefficient } & 0.04 & 0.03 & 0.03 & 0.14 \\
\hline & 0.12 & 0.09 & 0.07 & 0.13 \\
\hline \multirow[t]{2}{*}{ Concentration index } & 0.01 & 0.01 & 0.02 & 0.05 \\
\hline & 0.02 & -0.01 & 0.04 & 0.06 \\
\hline \multicolumn{5}{|l|}{ Based on regression models $(n=24)$} \\
\hline \multirow[t]{2}{*}{ Effect index } & -0.07 & 0.02 & -0.15 & -0.32 \\
\hline & -0.00 & 0.00 & -0.00 & -0.00 \\
\hline \multirow[t]{2}{*}{ Inequality slope } & 4.34 & -2.32 & 6.76 & 16.45 \\
\hline & 0.09 & -0.08 & 0.04 & 0.08 \\
\hline \multirow[t]{2}{*}{ Pamuk inequality or relative } & 0.05 & 0.03 & 0.08 & 0.22 \\
\hline & 0.16 & 0.07 & 0.08 & 0.21 \\
\hline \multirow[t]{2}{*}{ Kunst and Mackenbach inequality } & 1.05 & 1.03 & 1.08 & 1.20 \\
\hline & 1.15 & 1.07 & 1.08 & 1.19 \\
\hline \multirow[t]{2}{*}{ Bounded inequality } & 0.95 & 1.02 & 0.93 & 0.82 \\
\hline & 0.87 & 1.07 & 0.93 & 0.83 \\
\hline \multicolumn{5}{|l|}{ Based on the concept of entropy $(n=33)$} \\
\hline \multirow[t]{2}{*}{ Kullback-Liebler (Z score) } & 0.00 & 0.00 & 0.00 & 0.02 \\
\hline & 0.02 & 0.01 & 0.01 & 0.03 \\
\hline \multirow[t]{2}{*}{ Hoover or dissimilarities (Z score) } & 0.03 & 0.03 & 0.02 & 0.08 \\
\hline & 0.08 & 0.06 & 0.05 & 0.10 \\
\hline Theil (Z score) & 0.00 & 0.00 & 0.00 & 0.00 \\
\hline & 0.08 & 0.06 & 0.05 & 0.10 \\
\hline
\end{tabular}

* For all calculations the sense of economic variable was negative, in the health variable is positive;

** $\mathrm{n}$ is 24 that the monetary poverty data is necessary;

*** For all indexes the first line is based on the mean prevalence of use (\%);

\# For all indexes the first line is based on the mean frequency/day of consumption (times/day). 
transporting and preserving them, the social value of their consumption, or the perception of the role of fruits or vegetables in the preservation of health or recovery from disease 7,21,23,46.

The poverty or economic status effect on fruits and vegetables consumption is not generalizable and depends on other elements and environmental interactions. Economic status effects are context specific 22. Among Uruguayan adolescents, fruits and vegetables consumption is higher among the poorest 17 , in contrast to the findings reported herein regarding the prevalence of fruits and vegetables consumption among adults. Other reports show higher fruits and vegetables consumption among higher socioeconomic strata 16,19 . However, a comparative study performed in seven countries on different continents, which established the relationship between fruits and vegetables consumption and neighborhood socioeconomic status, concluded that this relationship is context specific 22. Combining or adding fruits and vegetables consumption may distort relationships with socioeconomic variables and render our findings non-comparable.

In Colombia, few studies have assessed inequality based on nutritional variables and fruits and vegetables consumption. Nevertheless, the indices reported herein are lower than those of other studied nutritional variables based on the ENSIN-2010 49 and are dynamic development indicators that complement other structural indicators, including multidimensional poverty and education level. Canadian and British adults show a socioeconomic gradient in the frequency of fruits and vegetables consumption/day, with low-income and low-education groups consuming fruits and vegetables fewer times per day than high-income and high-education groups 19,21. There are also significant differences in the frequency of fruits and vegetables consumption per day based on demographic and lifestyle characteristics. In Canada, studies have shown that the frequency of fruits and vegetables consumption per day is relatively lower among males, middle-aged persons, single persons, smokers, individuals with weak social interaction, and childless households. In particular, the higher individuals' education level is, the higher their frequency of fruits and vegetables consumption per day will be. Furthermore, the variation in fruits and vegetables consumption with age has a U-shaped pattern 21. This study precludes comparisons between these variables. The study of determinants of fruits and vegetables consumption in Colombia was based on the classical approach of food security, production, trade, availability, and consumption using integrated secondary data 42.

The higher inequality shown in the consumption of cooked vegetables may be caused by socioeconomic and cultural phenomena, including the stewing tradition or low-food culture, which contrasts with the fast-food culture. This situation is consistent with the current state of food transition in Colombia, in which the poor follow the traditional diet more than the rich do 24,25. Furthermore, ignorance of the nutritional properties of fruits and vegetables due to low education level 50 and limitations in fruits and vegetables supply in the grocery stores and pantries of poor neighborhoods 51 may also explain the higher inequality because the cold chain is an actual barrier that further increases the price of food in poor neighborhoods than in wealthy neighborhoods, as previously shown 8,9,16,51 - decreasing intermediation to bring producers and consumers closer, especially in poor neighborhoods, may decrease prices and increase supply. Other possible explanations are the different relationships between subjects and the production system due to their socioeconomic status or beliefs about the disinfecting power of heat in food cooking. These are hypotheses to be investigated and about which we cannot argue based on scientific evidence.

In this study, inequalities are expressed at a level of detail that is usually undervalued in assessments of distributive social justice. The indicators reported herein mostly show dynamic inequalities resulting from socioeconomic growth. This study is part of a line of research on health equity, which is a fundamental aspect of the justice of social contracts. Economic inequalities in nutrition persist in vulnerable and poor groups.

\section{Study scope and limitations}

The limitations of this study are similar to all studies conducted at the ecological level. The main limitation is the inclusion of average data from the geodemographic units of Colombia, which precludes inferences specific to groups within these units. Another limitation is that the values of the variables used in the calculations may express other determinant variables not included in the study. Nevertheless, ecological studies incorporate complex gradients of the development of geodemographic units 
that summarize these differences in development levels into a few variables, such as monetary poverty and the prevalence and frequency of consumption/day, thereby providing greater discriminatory power between the study variables 52 . One final limitation is the question about the validity of the scale used in the ENSIN-2010 to measure food security in households 53,54. None of the limitations have implications that could invalidate or raise questions about the results reported in this study.

In conclusion, the results showed that one to two of every ten adults in Colombia eats no fruits and that three to four of every ten adults eats no vegetables. The frequency of consumption/day is far from meeting WHO recommendations since, at best, the frequency is 1.6 times/day [frequency/day for fruit juice consumption among women] and, at worst, 0.1 times/day [frequency/day for cooked vegetables in several geodemographic units]. Furthermore, fruit juices are preferred to whole fruits, and neither the frequency/day nor the prevalence of consumption of fruits, either as fruit juice or whole fruit, differs between sexes. At the ecological level, the relationship between monetary poverty and the study variables is apparently weak. However, at the individual level, or when population size is incorporated into geodemographic units, the weighed analysis shows a relationship between poverty and the fruits and vegetables consumption: the lower the poverty level is, the higher the prevalence and frequency of consumption/day of fruits and vegetables will be. Inequalities identified through the different indices consistently show that women have, with few exceptions, lower inequality than men in fruits and vegetables consumption.

\section{Contributors}

O. F. Herran designed the study, obtained the databases from the ICBF, prepared the databases and conducted and led statistical analyses. O. F. Herran, E. M. Gamboa and G. A. Patiño interpreted the results, prepared, reviewed and wrote the manuscript. All authors reviewed the manuscript and approved the final version.

\section{Additional informations}

ORCID: Oscar Fernando Herran (0000-0002-25098636); Gonzalo Alberto Patiño (0000-0003-42007350); Edna Magaly Gamboa (0000-0002-61445877).

\section{References}

1. Denova-Gutiérrez E, Tucker KL, Flores M, Barquera S, Salmerón J. Dietary patterns are associated with predicted cardiovascular disease risk in an urban Mexican adult population. J Nutr 2016; 146:90-7.

2. Agudo A. Measuring intake of fruit and vegetables. Geneva: World Health Organization; 2005.

3. World Cancer Research Fund; American Institute for Cancer Research. Fruit and vegetables. Handbook of cancer prevention. Washington DC: World Cancer Research Fund; 2003.

4. World Health Organization. Fruit, vegetables and NCD disease prevention. Global, strategy on diet physical activity and health. Geneva: World Health Organization; 2002.

5. Sacks R, Yi SS, Nonas C. Increasing access to fruits and vegetables: perspectives from the New York City experience. Am J Public Health 2015; 105:e29-e37.

6. van Lenthe FJ, Jansen T, Kamphuis CB. Understanding socio-economic inequalities in food choice behaviour: can Maslow's pyramid help? Br J Nutr 2015; 113:1139-47.

7. Olivares S, Lera L, Bustos N. Etapas del cambio, beneficios y barreras en actividad física y consumo de frutas y verduras en estudiantes universitarios de Santiago de Chile. Rev Chil Nutr 2008; 35:25-35.

8. Prada GE, Dubeibe-Blanco LY, Herrán OF, Herrera-Anaya M. Evaluation of the impact of a community intervention on the consumption of fruits and vegetables in Colombia. Salud Pública Méx 2007; 49:11-9. 
9. Prada GE, Herrán OF. Impacto de estrategias para aumentar el consumo de frutas y verduras en Colombia. Rev Chil Nutr 2009; 36:1080-9.

10. Lock K, Pomerleau J, Causer L, Altmann DR, McKee M. The global burden of disease attributable to low consumption of fruit and vegetables: implications for theglobal strategy on diet. Bull World Health Organ 2005; 83:100-8.

11. Eaton DK, Kann L, Kinchen S, Shanklin S, Flint KH, Hawkins J, et al. Youth risk behavior surveillance - United States, 2011. MMWR Surveill Summ 2012; 61:1-162.

12. World Health Organization. Diet, nutrition and the prevention of chronic diseases. Report of a Joint WHO/FAO Expert Consultation. Geneva: World Health Organization; 2003. (WHO Technical Report Series, 916).

13. Jacob RA, Burri BJ. Oxidative damage and defense. Am J Clin Nutr 1996; 63:985S-90S.

14. Agudo A, Cabrera L, Amiano P, Ardanaz E, Barricarte A, Berenguer T, et al. Fruit and vegetable intakes, dietary antioxidant nutrients, and total mortality in Spanish adults: findings from the Spanish cohort of the European prospective investigation into Cancer and nutrition (EPIC-Spain). Am J Clin Nutr 2007; 85:1634-42.

15. Knekt P, Ritz J, Pereira MA, O’Reilly EJ, Augustsson K, Fraser GE, et al. Antioxidant vitamins and coronary heart disease risk: a pooled analysis of 9 cohorts. Am J Clin Nutr 2004; 80:1508-20.

16. Pessoa MC, Mendes LL, Gomes CS, Martins PA, Velasquez-Melendez G. Food environment and fruit and vegetable intake in a urban population: a multilevel analysis. BMC Public Health 2015; 15:1012.

17. Ortiz A, Pereyra I. Study of food characteristics of Uruguayan adolescents. Arch Latinoam Nutr 2015; 65:97-103.

18. Teixeira MG, Mill JG, Pereira AC, Molina MC. Dietary intake of antioxidant in ELSA-Brasil population: baseline results. Rev Bras Epidemiol 2016; 19:149-59.

19. Mackenbach JD, Brage S, Forouhi NG, Griffin SJ, Wareham NJ, Monsivais P. Does the importance of dietary costs for fruit and vegetable intake vary by socioeconomic position? $\mathrm{Br} \mathrm{J}$ Nutr 2015; 114:1464-70.

20. Pienovi L, Lara M, Bustos P, Amigo H. Fruit and vegetable intake, and blood pressure: a population research. Arch Latinoam Nutr 2015; 65:21-6.

21. Azagba S, Sharaf MF. Disparities in the frequency of fruit and vegetable consumption by socio-demographic and lifestyle characteristics in Canada. Nutr J 2011; 10:118.

22. Ball K, Lamb KE, Costa C, Cutumisu N, Ellaway A, Kamphuis CB, et al. Neighbourhood socioeconomic disadvantage and fruit and vegetable consumption: a seven countries comparison. Int J Behav Nutr Phys Act 2015; 12:68.
23. Haynes-Maslow L, Auvergne L, Mark B, Ammerman A, Weiner BJ. Low-income individuals' perceptions about fruit and vegetable access programs: a qualitative study. J Nutr Educ Behav 2015; 47:317-24.e1.

24. Ocampo PR, Prada GE, Herrán OF. Patrones de consumo alimentario y exceso de peso infantil: Encuesta de la Situación Nutricional en Colombia, 2010. Rev Chil Nutr 2014; 41:351-9.

25. Herrán OF, Patiño GA, Del Castillo SE. Dietary transition and excess weight in adults according to the Encuesta de la Situación Nutricional en Colombia, 2010. Biomédica 2016; 36:10920.

26. Angulo-Salazar RC, Díaz-Cuervo Y, PardoPinzón R. Índice de Pobreza Multidimensional para Colombia (IPM-Colombia) 1997-2010. https://colaboracion.dnp.gov.co/CDT/Estu dios\%20Econmicos/382.pdf (accessed on 08/ Jul/2016).

27. Whitehead M. Los conceptos y principios de la equidad en salud. Washington DC: Organización Panamericana de la Salud; 1991.

28. Acheson D, Alleyne GA, Casas JA, Castillo-Salgado C, Barzach M, Braveman $\mathrm{P}$, et al. Round table discussion. Health inequalities and the health of the poor. Bull World Health Organ 2000; 78:75-6.

29. World Health Organization. The World Health Report. Health systems: improving performance. Geneva: World Health Organization; 2000.

30. Sen A. Why should there be equity in health? Rev Panam Salud Pública 2002; 11:302-9.

31. Schneider MC, Castillo-Salgado C, Bacallao J, Loyola E, Mujica OJ, Vidaurre M, et al. Methods for measuring inequalities in health. Rev Panam Salud Pública 2002; 12:398-414.

32. Instituto Colombiano de Bienestar Familiar. Encuesta Nacional de la Situación Nutricional en Colombia. Protocolo de investigación. https://www.minsalud.gov.co/sites/rid/ Lists/BibliotecaDigital/RIDE/VS/ED/GCFI/ Base\%20de\%20datos\%20ENSIN\%20-\%20Pro tocolo\%20Ensin\%202010.pdf (accessed on 03/ Nov/ 2014).

33. Departamento Administrativo Nacional de Estadística. Pobreza monetaria y multidimensional - 2011. https://www.dane.gov.co/ index.php/estadisticas-por-tema/pobreza-ycondiciones-de-vida/pobreza-y-desigualdad/ pobreza-y-desigualdad-2011 (accessed on 01/ Oct/2014).

34. Willet WC. Nutritional epidemiology. 3rd Ed. New York: Oxford University Press; 2013.

35. Margetts BM, Nelson M. Design concepts in nutritional epidemiology. 2nd Ed. Oxford: Oxford University Press; 2013. 
36. Ardila MF, Herrán OF. Desarrollo de un instrumento para medir la dieta en niños y adolescentes en la investigación epidemiológica. Rev Bras Saúde Matern Infant 2012; 12:365-74.

37. Herrán OF, Ardila MF, Rojas MP, Hernández GA. Design of dietary questionnaires to study the relationships between diet and cancer prevalence in Colombia. Biomédica 2010; 30:116-25.

38. Rutstein SO, Kiersten J. The DHS wealth index. Calverton: ORC Macro; 2004. (DHS Comparative Reports, 6).

39. Wehler CA, Scott RI, Anderson JJ. The community childhood hunger identification project: a model of domestic hunger - demonstration project in Seattle, Washington. J Nutr Educ 1992; 24 (1 Suppl 1):29S-35S.

40. Álvarez MC, Estrada A, Montoya EC, MelgarQuiñónez H. Validation of a household food security scale in Antioquia, Colombia. Salud Pública Méx 2006; 48:474-81.

41. Bacallao J, Castillo-Salgado C, Schneider MC, Mujica OJ, Loyola E, Vidaurre M. Índices para medir las desigualdades de salud de carácter social basados en la noción de entropía. Rev Panam Salud Pública 2006; 12:429-35.

42. Ministerio de Salud y Protección Social; Organización de las Naciones Unidas para la Alimentación y la Agricultura. Perfil nacional de consumo de frutas y verduras. Bogotá: Ministerio de Salud y Protección Social; 2013.

43. Ramírez-Silva I, Rivera JA, Ponce X, Hernández-Ávila M. Fruit and vegetable intake in the Mexican population: results from the Mexican National Health and Nutrition Survey 2006. Salud Pública Méx 2009; 51 Suppl 4:S574-85.

44. Jiménez-Aguilar A, Gaona-Pineda EB, MejíaRodríguez F, Gómez-Acosta LM, Méndez-Gómez Humarán I, Flores-Aldana M. Consumption of fruits and vegetables and health status of Mexican children from the National Health and Nutrition Survey 2012. Salud Pública Méx 2014; 56 Suppl 2:S103-12.
45. Instituto Nacional de Estadística e Informática. Perú: encuesta demográfica y de salud familiar; 2013. https://www.inei.gob.pe/me dia/MenuRecursivo/publicaciones_digitales/ Est/Lib1152/anexo01.html (accessed on 01/ Jun/2016).

46. Heuer T, Krems C, Moon K, Brombach C, Hoffmann I. Food consumption of adults in Germany: results of the German National Nutrition Survey II based on diet history interviews. Br J Nutr 2015; 113:1603-14.

47. Viera-Machado RH, Ferferbaum R, Leone C. Fruit intake and obesity. Fruit and vegetables consumption and obesity in Brazil. J Hum Growth Dev 2016; 26:243-52.

48. Håkansson A, Andersson HS, Granfeldt Y. Diet inequality prevails among consumers interested and knowledgeable in nutrition. Food Nutr Res 2015; 59:27601.

49. Herrán OF, Patiño GA, Del Castillo SE. Desigualdad y nutrición: análisis de la encuesta de la situación nutricional en Colombia, 2010. Rev Bras Saúde Matern Infant 2015; 15:401-12.

50. Moreira PA, Padrão PD. Educational and economic determinants of food intake in Portuguese adults: a cross-sectional survey. BMC Public Health 2004; 4:58.

51. Ayala GX, Baquero B, Pickrel JL, Mayer J, Belch G, Rock CL, et al. A store-based intervention to increase fruit and vegetable consumption: the El Valor de Nuestra Salud cluster randomized controlled trial. Contemp Clin Trials 2015; 42:228-38.

52. Mújica OJ. Cuatro cuestiones axiológicas de la epidemiología social para el monitoreo de la desigualdad en salud. Rev Panam Salud Pública 2015; 38:433-41.

53. Jiménez AZ, Prada GE, Herrán OF. Escalas para medir la seguridad alimentaria en Colombia. ¿Son válidas? Rev Chil Nutr 2012; 39:8-17.

54. Camargo MI, Quintero DC, Herrán OF. Seguridad alimentaria en Colombia y modelo Rasch. Rev Chil Nutr 2012; 39:168-80. 


\section{Resumen}

Con el fin de estimar las inequidades en el consumo de frutas y verduras, se realizó un estudio multinivel, basado en datos transversales de adultos de 18 a 64 años de edad $(n=5.217)$ y en unidades geodemográficas $(n=33)$. El consumo de frutas y verduras se estimó con un cuestionario de frecuencia de comidas, administrado como parte de la Encuesta Nacional de la Situación Nutricional (ENSIN), en Colombia, 2010. Los indices de inequidad para el consumo de frutas enteras $y$ zumo de frutas, así como para verduras crudas y cocinadas, se estimó usando datos sobre riqueza, seguridad alimentaria, área geográfica y pobreza monetaria. La prevalencia en el consumo de verduras cocidas fue de un 64,8\% (IC95\%: 59,2-70,4) entre hombres y la prevalencia del consumo de zumo de frutas fue 86,1\% (IC95\%: 82,4-89,8) entre mujeres. La frecuencia del consumo de zumo de fruta fue 1,03 veces/dia (IC95\%: 0,93-1,14) entre mujeres. La prevalencia y frecuencia de consumo de frutas y verduras al día, dentro de las tres variables socioeconómicas consideradas en este estudio, fue mayor según el nivel socioeconómico más alto $(p<0,05)$, salvo la frecuencia de consumo de frutas enteras/dia $(p=0,24)$. En el nivel individual el coeficiente de Gini para la frecuencia/día estuvo entre 0,51 y 0,62. En el nivel ecológico, el indice de Gini para la prevalencia estuvo entre 0,04 y 0,14 y para la frecuencia/día entre 0,03 y 0,11. La población colombiana no cumple con las recomendaciones en el consumo de frutas y verduras. Hombres y mujeres prefieren el consumo de zumos en lugar de frutas enteras. La inequidad en el consumo de verduras es clara, con los hombres con más desventaja. Los pobres comen menos frutas $y$ verduras.

Disparidades en el Estado de Salud; Frutas; Verduras; Encuestas Nutricionales

\section{Resumo}

Para estimar desigualdades no consumo de frutas e vegetais, um estudo multinível foi realizado baseado em dados seccionais de adultos entre 18 e 64 anos $(n=5.217)$ e em unidades geodemográficas $(n=33)$. O consumo de frutas e vegetais foi estimado por meio de um questionário de frequência alimentícia como parte do Inquérito Nacional de Situação Nutricional (ENSIN), Colômbia, 2010. Indices de desigualdade do consumo de frutas inteiras e suco de fruta e de vegetais crus e cozidos foram estumados usando dados sobre renda, segurança alimentar, área geográfica e pobreza monetária. A prevalência do consumo de vegetais cozidos foi de 64,8\% (IC95\%: 59,2-70,4) para os homens e a prevalência do consumo de suco de fruta foi de 86,1\% (IC95\%: 82,4-89,8) para as mulheres. A frequência do consumo de suco de fruta foi de 1,03 vezes/dia (IC95\%: 0,93-1,14) para as mulheres. A prevalência e frequência do consumo de frutas e vegetais por dia para as três variáveis socioeconômicas consideradas foram mais altas para o nivel socioeconômico mais alto $(p<0,05)$, exceto a frequência de consumo de frutas inteiras/ dia $(p=0,24)$. No nível individual, o coeficiente de Gini para a frequência/dia esteve entre 0,51 e 0,62. No nível ecológico, o indice de Gini para a prevalência esteve entre 0,04 e 0,4, para a frequência/dia, entre 0,03 e 0,11. A população colombiana não atinge as recomendações de consumo de frutas e vegetais. Homens e mulheres preferem consumir suco de fruto a frutas inteiras. A desigualdade no consumo de vegetais é clara, com desvantagem para os homens. Os pobres comem menos frutas e vegetais.

Disparidades nos Níveis de Saúde; Frutas; Verduras; Inquéritos Nutricionais
Submitted on 20/Feb/2018

Final version resubmitted on 07/Sep/2018 Approved on 20/Sep/2018 